\title{
Penerapan Algoritma C4.5 Untuk Penerimaan Siswa Baru Pada SMA Al-Azhar Medan
}

\author{
Dedek Indra Gunawan Hts \\ Universitas Potensi Utama \\ Jl. K. L. Yos Sudarso Km. 6,5 No. 3 A - Medan, 20241, Indonesia \\ dedek.indra@gmail.com
}

\begin{abstract}
Schools with good reputation are very concerned about the admission selection process. AlAzhar Medan High School is very concerned about this admission process. Every year many parents register their children to enter Al-Azhar High School Medan. Besides having good school facilities the teachers also have good competencies. The number of students who register makes the selection process take a long time. The C4.5 algorithm is one algorithm that changes the fact that is quite large into a decision tree. This algorithm is expected to be able to solve problems that occur in Al-Azhar High School Medan.
\end{abstract}

Keywords: Decision Support System, C4.5 Algorithm, Acceptance of Students

\begin{abstract}
Abstrak
Sekolah yang bereputasi baik sangat memperhatikan proses seleksi penerimaan siswa/i nya. SMA Al-Azhar Medan sangat memperhatikan proses penerimaan ini. Setiap tahun banyak orangtua yang mendaftarkan anak-anaknya untuk masuk SMA Al-Azhar Medan. Selain memiliki fasilitas sekolah yang baik guru-gurunya juga memiliki kompetensi yang baik. Banyaknya siswa/i yang mendaftar menjadikan proses seleksi memakan waktu yang cukup lama. Algoritma C4.5 merupakan salah satu algoritma yang mengubah fakta yang cukup besar menjadi sebuah pohon keputusan. Dengan algoritma ini diharapkan mampu menyelesaikan permasalahan yang terjadi di SMA Al-Azhar Medan.
\end{abstract}

Kata kunci: Sistem Pendukung Keputusan, Algoritma C4.5, Penerimaan Siswa

\section{PENDAHULUAN}

SMA AL-Azhar adalah salah satu sekolah yang terbaik di Kota Medan. Setiap tahunnya banyak para orangtua siswa yang ingin mendaftarkan anakanaknya ke sekolah tersebut. Banyaknya siswa yang mendaftar mengharuskan pihak sekolah mengadakan proses seleksi yang sangat ketat. Seleksi dilakukan agar pihak sekolah dapat mendidik siswa/i dengan maksimal. Para siswa harus mengikuti ujian Matematika, Bahasa Inggris dan Psikotes. Untuk masuk kelas Plus nilai ujian siswa harus di atas 6. Setelah proses tes kemampuan selesai, selanjutnya adalah para siswa harus mengikuti tes wawancara. Setelah tes wawancara selesai baru kemudian para siswa mengetahui hasilnya diterima di kelas Plus.

Proses penerimaan siswa di SMA Al-Azhar masih menggunakan perhitungan manual. Masing-masing tes dihitung baru kemudian diakumulasi. Hasil akumulasi tersebut yang menentukan apakah siswa tersebut masuk kelas Plus atau Akselerasi. Banyaknya siswa yang mengikuti ujian seleksi tentu membuat proses penilaian menjadi semakin lambat. Untuk 
itulah dibutuhkan suatu metode untuk mempercepat proses penerimaan siswa baru di sekolah SMA Al-Azhar Medan.

Algoritma C4.5 merupakan salah satu metode yang bisa mengubah fakta yang sangat besar menjadi pohon keputusan yang merepresentasikan aturan[1]. Hasil tes seluruh setiap siswa diproses menggunakan algoritma C4.5 sehingga menghasilkan kesimpulan siapa saja siswa yang masuk kelas Plus atau Akselerasi. Dengan adanya sistem klasifikasi ini maka pihak sekolah dapat menentukan siapa saja siswa yang masuk kelas Plus dan Akselerasi. Sehingga proses penerimaan siswa menjadi lebih cepat.

\section{METODOLOGI PENELITIAN}

Metode penelitian sangat penting untuk membantu penulis dalam menyelesaikan masalah diatas. Metode penelitian dapat dilihat pada gambar kerangka kerja dibawah ini:

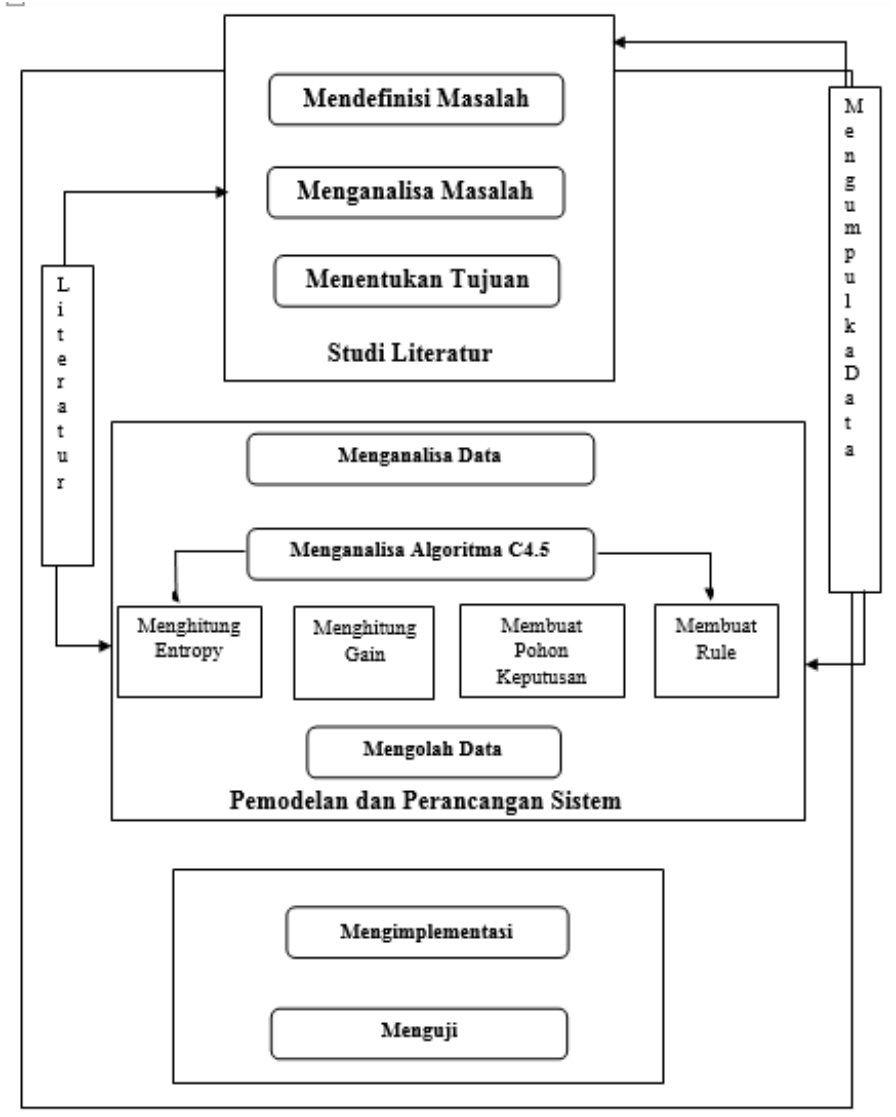

Gambar 1. Metode Penelitian

a) Mendefinisi Masalah

Pada tahap ini dilakukan peninjauan ke sistem yang akan diteliti untuk mengamati serta melakukan eksplorasi lebih dalam dan menggali permasalahan yang ada pada sistem yang berjalan saat ini. Tahap ini adalah langkah awal untuk menentukan rumusan masalah dari penelitian. 
b) Menganalisa Masalah

Permasalahan yang ditemukan kemudian akan di analisa. Langkah dalam proses analisa masalah adalah langkah untuk memahami masalah yang telah ditentukan. Dengan menganalisa permasalahan yang telah ditentukan tersebut, maka diharapkan masalah tersebut dapat dipahami dengan baik.

c) Menentukan Tujuan

Berdasarkan pemahaman dari permasalahan yang telah di analisa, langkah berikutnya adalah menentukan tujuan yang akan dicapai dalam penelitian ini. Tujuan yang akan dicapai merupakan pengetahuan yang dapat digunakan untuk pengambilan keputusan dalam penerimaan siswa baru pada SMA AL-Azhar Medan.

d) Mempelajari Literatur

Penelitian ini dilakukan untuk melengkapi perbendaharaan kaidah, konsep, teori-teori yang mendukung dalam penyelesaian masalah dalam penelitian ini. Penelitian juga dilakukan melalui jurnal-jurnal yang ada hubunganya dengan penelitian maupun refrensi yang lain. Penelitian ini bertujuan untuk mengumpulkan data, baik data pokok maupun data pendukung, dimana semua data tersebut sangat dibutuhkan dalam penelitian.

e) Mengumpulkan Data

Mengumpulkan data untuk pelatihan dan pengujian C4.5. Semakin banyak data diperoleh, semakin baik dalam meyelesaikan masalahnya. Mengumpulkan data yang akurat dan membagi data tersebut ke dalam kriteria yang sudah ditentukan. Pembagian kriteria digunakan untuk mempermudah dalam pengelompokan data

f) Menganalisa Algoritma C4.5

Setelah data dikumpulkan dilakukan analisa data untuk menyesuaikan proses data yang akan diolah pada Algoritma C4.5, dimana tahapan yang dilakukan pada Algoritma C4.5 dimulai dengan menghitung entropy, menghitung gain, membuat pohon keputusan dan membuat rule.

g) Mengolahan Data

Setelah proses analisa metode pada tahap ini dilakukan pengolaan data yang terdiri dari beberapa tahapan untuk menghasilkan pohon keputusan yaitu Untuk memilih atribut sebagai akar, didasarkan pada nilai gain tertinggi dari atribut-atribut yang ada.

h) Mengimplementasi

Sesuai dengan pengolahan data maka pada tahap implementasi adalah tentang bagaimana pengolahan datanya diterapkan dalam sebuah tools.

i) Menguji

Pada tahap ini, dilakukan penilaian apakah perangkat lunak yang dikembangkan telah sesuai dengan tujuan yang diharapkan. Berikut ini adalah mekanisme pengujian yang dilakukan: 
1. Membangun suatu kasus uji yaitu sekumpulan data atau situasi yang akan digunakan dalam pengujian.

2. Menentukan hasil yang akan diharapkan dengan cara melakukan proses perhitungan manual.

3. Menjalankan kasus pengujian

Melakukan perbandingan hasil pengujian dan hasil yang diharapkan, jika terdapat perbedaan hasil maka akan dilakukan perbaikan sesuai dengan kesalahan yang ditemukan.

\subsection{Knowledge Discovery in Database}

Istilah data mining dan knowledge discovery in database (KDD) sering kali digunakan secara bergantian untuk menjelaskan proses penggalian informasi tersembunyi dalam suatu basis data yang besar[2]. Sebenarnya kedua istilah tersebut memiliki konsep yang berbeda, tetapi berkaitan satu sama lain. Dan salah satu tahapan dalam keseluruhan proses KDD adalah data mining. Proses KDD secara garis besar dapat dijelaskan sebagai berikut:
a. Data Selection
b. Pre- processing / Cleaning
c. Transformation
d. Data mining
e. Interpretation / Evaluation

Pola informasi yang dihasilkan dari proses data mining perlu ditampilkan dalam bentuk yang mudah dimengerti oleh pihak yang berkepentingan. Tahap ini merupakan bagian dari proses KDD yang disebut interpretation. Tahap ini mencakup pemeriksaan apakah pola atau informasi yang ditemukan bertentangan dengan fakta atau hipotesis yang ada sebelumnya.

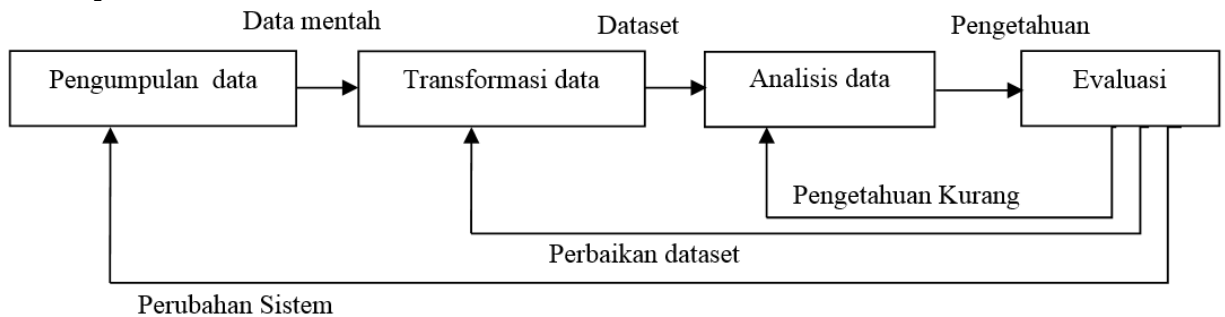

Gambar 2. Aliran Informasi dalam Data Mining

\subsection{Data Mining}

Data mining (DM) adalah suatu istilah yang digunakan untuk menguraikan penemuan pengetahuan di dalam database [3]. Data mining adalah suatu proses yang menggunakan teknik statistik, matematika, kecerdasan tiruan dan machine-learning untuk mengekstraksi dan mengidentifikasi informasi yang bermanfaat dan pengetahuan yang terkait dari berbagai database besar[4][5]. Hubungan yang dicari dalam data mining dapat berupa hubugan antara dua atau lebih dalam satu dimensi. Misalnya 
dalam dimensi produk kita dapat melihat keterkaitan pembelian suatu produk dengan produk yang lain. Selain itu, hubungan juga dapat dilihat antara dua atau lebih atribut dan dua atau lebih objek.

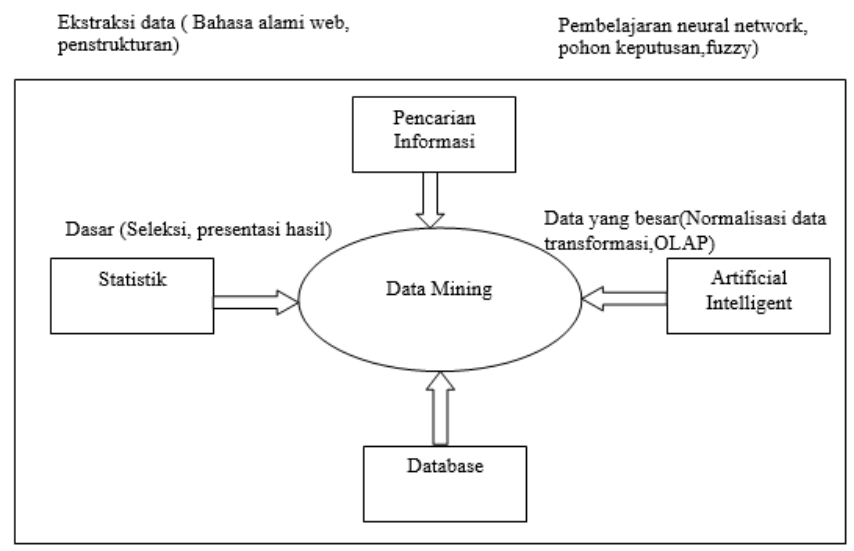

Gambar 3. Pengelompokkan Data Mining

\subsection{Klasifikasi}

Klasifikasi adalah proses penemuan model yang menggambarkan dan membedakan kelas data atau konsep yang bertujuan agar bias digunakan untuk mempediksi kelas dari obyek yang label kelasnya tidak diketahui. Klasifikasi data terdiri dari 2 langkah proses. Pertama adalah learning (fase training), dimana algoritma klasifikasi dibuat untuk menganalisa data training lalu direpresentasikan dalam bentuk rule klasifikasi. Proses kedua adalah klasifikasi, dimana data tes digunakan untuk memperkirakan akurasi dari rule klasifikasi

\subsection{Algoritma C4.5}

Banyak algoritma yang dapat dipakai dalam pembentukan pohon keputusan, antara lain ID3, CART, dan C4.5 [2]. Algoritma C4.5 merupakan pengembangan dari algoritma ID3. Pohon keputusan merupakan metode klasifikasi dan prediksi yang sangat kuat dan terkenal. Metode pohon keputusan mengubah fakta yang sangat besar menjadi pohon keputusan yang memprediksikan aturan. Aturan dapat dengan mudah dipahami dengan alami. Dan mereka juga dapat diekspresikan dalam bentuk bahasa basis data seperti Structured Query Language untuk mencari record pada kategori tertentu [2]. Secara umum algoritma C4.5 untuk membangun pohon keputusan adalah sebagai berikut:

1. Pilih atribut sebagai akar

2. Buat cabang untuk tiap nilai

3. Bagi kasus dalam cabang

4. Ulangi proses untuk setiap cabang sampai semua kasus pada cabang memiliki kelas yang sama. 
Untuk memilih atribut sebagai akar, didasarkan pada nilai gain tertinggi dari atribut-atribut yang ada. Untuk menghitung gain digunakan rumus di bawah ini :

$$
\operatorname{Gain}(S, A)=\operatorname{Entropy}(S)-\sum_{i=1}^{n} \frac{\left|S_{i}\right|}{|S|} * \operatorname{Entropy}(S i)
$$

Di mana:

$S \quad=$ Himpunan kasus

$A \quad=$ Atribut

$n \quad=$ Jumlah partisi atribut A

$\left|S_{i}\right| \quad=$ Jumlah kasus pada partisi ke-i

$|S| \quad=$ Jumlah kasus dalam $S$

Sementara itu, perhitungan nilai entropy adalah seperti persamaan 2 di bawah ini :

$$
\operatorname{Entropy}(S)=\sum_{i=1}^{n}-p i * \log _{2} p i
$$

Di mana:

$$
\begin{array}{ll}
S & =\text { Himpunan kasus } \\
n & =\text { Jumlah partisi } \mathrm{S} \\
A & =\text { Fitur } \\
P i & =\text { Proporsi dari }\left|\mathrm{S}_{\mathrm{i}}\right| \text { terhadap } \mathrm{S}
\end{array}
$$

Dalam hal ini mengubah tree yang dihasilkan dalam beberapa rule dimana jumlah rule sama dengan jumlah path yang dibangun dari root sampai leaf node. Ada istilah Tree Pruning yang dilakukan untuk menyederhanakan tree sehingga akurasi dapat bertambah. Pruning ada dua pendekatan, yaitu:

a. Pre-pruning

yaitu menghentikan pembangunan suatu subtree lebih awal (yaitu dengan memutuskan untuk tidak lebih jauh mempartisi data training). Saat seketika berhenti, maka node berubah menjadi leaf (node akhir). Node akhir ini menjadi kelas yang paling sering muncul di antarasubset sampel.

b. Post-pruning

yaitu menyederhanakan tree dengan cara membuang beberapa cabang subtree setelah tree selesai dibangun. Node yang jarang dipotong akan menjadi leaf (node akhir) dengan kelas yang paling sering muncul.

\section{HASIL DAN PEMBAHASAN}

\subsection{Proses Pembentukan Pohon Keputusan}

Berikut ini beberapa langkah dalam pembentukan pohon keputusan menggunakan algoritma C4.5

\subsubsection{Inisiasi}

Berdasarkan tabel 1 dapat diketahui bahwa atribut dengan Gain tertinggi adalah Wawancara, yaitu Sebesar 1,0695692. Dengan demikian, 
Wawancara dapat menjadi node akar. Ada dua nilai atribut yaitu $<7$ dan $>7$. Hasil perhitungan entropy dan gain diperoleh hasil seperti pada Tabel 1.

Tabel 1. Hasil Perhitungan Entropy dan Gain Akar

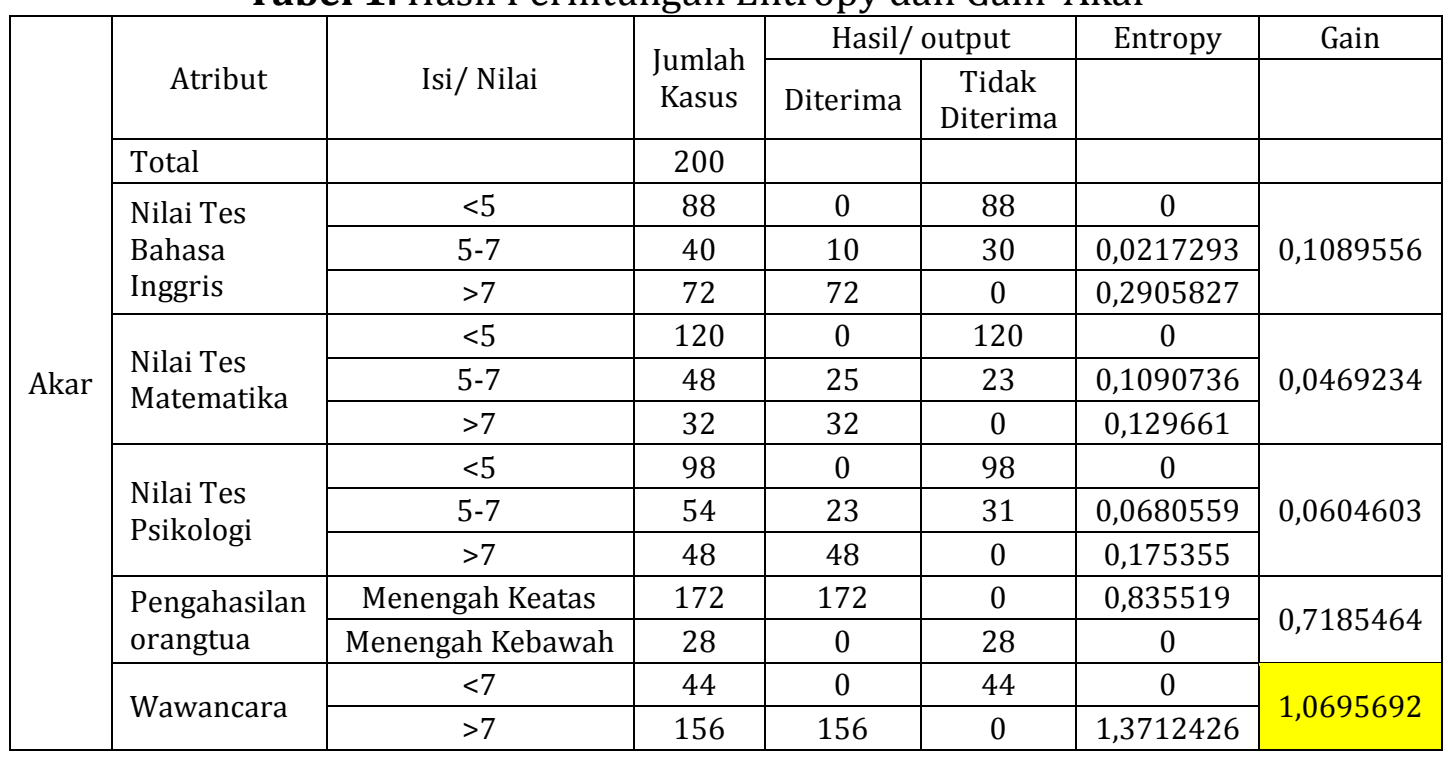

\subsubsection{Inisiasi Pertama}

Berdasarkan tabel 2 dapat diketahui bahwa atribut dengan Gain tertinggi adalah Penghasilan Orangtua, yaitu Sebesar 0,646867377. Dengan demikian, Penghasilan Orangtua menjadi cabang berikutnya. Ada dua nilai atribut yaitu Menengah Keatas dan Menengah Kebawah. Hasil perhitungan entropy dan gain diperoleh hasil seperti pada Tabel 2.

Tabel 2. Hasil Perhitungan Entropy dan Gain Level I

\begin{tabular}{|c|c|c|c|c|c|c|c|}
\hline \multirow{14}{*}{$\begin{array}{l}\text { Level } \\
\quad 1\end{array}$} & \multirow[b]{2}{*}{ Atribut } & \multirow[b]{2}{*}{ Isi/ Nilai } & \multirow{2}{*}{$\begin{array}{l}\text { Jumlah } \\
\text { Kasus }\end{array}$} & \multicolumn{2}{|c|}{ Hasil/ output } & \multirow[b]{2}{*}{ Entropy } & \multirow[b]{2}{*}{ Gain } \\
\hline & & & & Diterima & $\begin{array}{l}\text { Tidak } \\
\text { Diterima }\end{array}$ & & \\
\hline & Wawancara & & 156 & & & & \\
\hline & \multirow{3}{*}{$\begin{array}{c}\text { Nilai Tes Bahasa } \\
\text { Inggris }\end{array}$} & $<5$ & 88 & 0 & 88 & 0 & \multirow{3}{*}{0,033170831} \\
\hline & & $5-7$ & 34 & 0 & 34 & 0 & \\
\hline & & $>7$ & 34 & 34 & 0 & 0,152195578 & \\
\hline & \multirow{3}{*}{$\begin{array}{l}\text { Nilai Tes } \\
\text { Matematika }\end{array}$} & $<5$ & 70 & 0 & 120 & 0 & \multirow{3}{*}{0,147097054} \\
\hline & & $5-7$ & 30 & 0 & 30 & 0 & \\
\hline & & $>7$ & 56 & 56 & 0 & 0,409770366 & \\
\hline & \multirow{3}{*}{$\begin{array}{l}\text { Nilai Tes } \\
\text { Psikologi }\end{array}$} & $<5$ & 98 & 0 & 98 & 0 & \multirow{3}{*}{0,042741749} \\
\hline & & $5-7$ & 20 & 0 & 20 & 0 & \\
\hline & & $>7$ & 38 & 38 & 0 & 0,175466128 & \\
\hline & \multirow{2}{*}{$\begin{array}{l}\text { Pengahasilan } \\
\text { orangtua }\end{array}$} & Menengah Keatas & 128 & 128 & 0 & 0,788369615 & \multirow{2}{*}{0,646867377} \\
\hline & & Menengah Kebawah & 28 & 0 & 28 & 0 & \\
\hline
\end{tabular}

\subsubsection{Inisiasi Kedua}

Berdasarkan tabel 3 dapat diketahui bahwa atribut dengan Gain tertinggi adalah Nilai Psikotes, yaitu Sebesar 0,093781188. Dengan demikian, 
Nilai Psikotes menjadi cabang berikutnya. Ada tiga nilai atribut yaitu $<5,5-7$, $>7$. Hasil perhitungan entropy dan gain diperoleh hasil seperti pada Tabel 3.

Tabel 3. Hasil Perhitungan Entropy dan Gain Level II

\begin{tabular}{|c|c|c|c|c|c|c|c|}
\hline \multirow{12}{*}{$\begin{array}{l}\text { Level } \\
\text { II }\end{array}$} & \multirow[b]{2}{*}{ Atribut } & \multirow[b]{2}{*}{ Isi/ Nilai } & \multirow{2}{*}{$\begin{array}{l}\text { Jumlah } \\
\text { Kasus }\end{array}$} & \multicolumn{2}{|c|}{ Hasil/ output } & \multirow[b]{2}{*}{ Entropy } & \multirow[b]{2}{*}{ Gain } \\
\hline & & & & Diterima & $\begin{array}{l}\text { Tidak } \\
\text { Diterima }\end{array}$ & & \\
\hline & $\begin{array}{l}\text { Wawancara, } \\
\text { Penghasilan } \\
\text { Orangtua }\end{array}$ & & 128 & & & & \\
\hline & \multirow{3}{*}{$\begin{array}{l}\text { Nilai Tes } \\
\text { Bahasa Inggris }\end{array}$} & $<5$ & 85 & 0 & 88 & 0 & \multirow{3}{*}{0,025307008} \\
\hline & & $5-7$ & 18 & 0 & 18 & 0 & \\
\hline & & $>7$ & 25 & 25 & 0 & 0,12957188 & \\
\hline & \multirow{3}{*}{$\begin{array}{l}\text { Nilai Tes } \\
\text { Matematika }\end{array}$} & $<5$ & 77 & 0 & 77 & 0 & \multirow{3}{*}{0,053918258} \\
\hline & & $5-7$ & 25 & 10 & 15 & 0,062237482 & \\
\hline & & $>7$ & 26 & 26 & 0 & 0,205599997 & \\
\hline & \multirow{3}{*}{$\begin{array}{l}\text { Nilai Tes } \\
\text { Psikologi }\end{array}$} & $<5$ & 70 & 0 & 70 & 0 & \multirow{3}{*}{0,093781188} \\
\hline & & $5-7$ & 12 & 6 & 6 & 0,017310017 & \\
\hline & & $>7$ & 44 & 44 & 0 & 0,268097088 & \\
\hline
\end{tabular}

\subsubsection{Inisiasi Ketiga}

Berdasarkan tabel 4 dapat diketahui bahwa atribut dengan Gain tertinggi adalah Nilai Matematika, yaitu Sebesar 0,664037053. Dengan demikian, Nilai Psikotes menjadi cabang berikutnya. Ada tiga nilai atribut yaitu $<5,5-7$, $>7$. Hasil perhitungan entropy dan gain diperoleh hasil seperti pada Tabel 4 .

Tabel 4. Hasil Perhitungan Entropy dan Gain Level III

\begin{tabular}{|c|c|c|c|c|c|c|c|}
\hline \multirow{9}{*}{$\begin{array}{l}\text { Level } \\
\text { III }\end{array}$} & \multirow[b]{2}{*}{ Atribut } & \multirow[b]{2}{*}{ Isi/ Nilai } & \multirow[b]{2}{*}{$\begin{array}{c}\text { Jumlah } \\
\text { Kasus }\end{array}$} & \multicolumn{2}{|c|}{ Hasil/ output } & \multirow[b]{2}{*}{ Entropy } & \multirow[b]{2}{*}{ Gain } \\
\hline & & & & Diterima & $\begin{array}{l}\text { Tidak } \\
\text { Diterima }\end{array}$ & & \\
\hline & $\begin{array}{l}\text { Wawancara, } \\
\text { Penghasilan } \\
\text { Orangtua, Nilai Tes } \\
\text { Psikologi }\end{array}$ & & 50 & & & & \\
\hline & \multirow{3}{*}{$\begin{array}{l}\text { Nilai Tes Bahasa } \\
\text { Inggris }\end{array}$} & $<4$ & 0 & 0 & 0 & 0 & \multirow{3}{*}{0,44532472} \\
\hline & & $5-7$ & 15 & 0 & 15 & 0 & \\
\hline & & $>7$ & 35 & 35 & 0 & 0,636178172 & \\
\hline & \multirow{3}{*}{$\begin{array}{l}\text { Nilai Tes } \\
\text { Matematika }\end{array}$} & $<5$ & 0 & 0 & 120 & 0 & \multirow{3}{*}{0,664037053} \\
\hline & & $5-7$ & 10 & 0 & 10 & 0 & \\
\hline & & $>7$ & 40 & 40 & 0 & 0,830046317 & \\
\hline
\end{tabular}

\subsubsection{Inisiasi Keempat}

Berdasarkan tabel 5 dapat diketahui bahwa atribut dengan Gain tertinggi adalah Nilai Matematika, yaitu Sebesar 0,340855098. Dengan demikian, Nilai Psikotes menjadi cabang berikutnya. Ada tiga nilai atribut yaitu <5, 5-7, $>7$. Hasil perhitungan entropy dan gain diperoleh hasil seperti pada Tabel 5. 
Tabel 5. Hasil Perhitungan Entropy dan Gain Level IV

\begin{tabular}{|c|c|c|c|c|c|c|c|}
\hline \multirow{6}{*}{$\begin{array}{l}\text { Level } \\
\text { IV }\end{array}$} & \multirow[b]{2}{*}{ Atribut } & \multirow[b]{2}{*}{ Isi/ Nilai } & \multirow[b]{2}{*}{$\begin{array}{c}\text { Jumlah } \\
\text { Kasus }\end{array}$} & \multicolumn{2}{|c|}{ Hasil/ output } & \multirow[b]{2}{*}{ Entropy } & \multirow[b]{2}{*}{ Gain } \\
\hline & & & & Diterima & $\begin{array}{l}\text { Tidak } \\
\text { Diterima }\end{array}$ & & \\
\hline & $\begin{array}{l}\text { Wawancara, } \\
\text { Penghasilan } \\
\text { Orangtua, Nilai Tes } \\
\text { Psikologi, Nilai Tes } \\
\text { Matematika }\end{array}$ & & 40 & & & & \\
\hline & \multirow{3}{*}{$\begin{array}{l}\text { Nilai Tes Bahasa } \\
\text { Inggris }\end{array}$} & $<4$ & 0 & 0 & 88 & 0 & \multirow{3}{*}{0,340855098} \\
\hline & & $5-7$ & 15 & 0 & 40 & 0 & \\
\hline & & $>7$ & 25 & 25 & 0 & 0,545368157 & \\
\hline
\end{tabular}

Hasil perhitungan Entropy dan Gain Mencari Cabang Level 1 dalam bentuk pohon keputusan dapat dilihat pada gambar 4 .

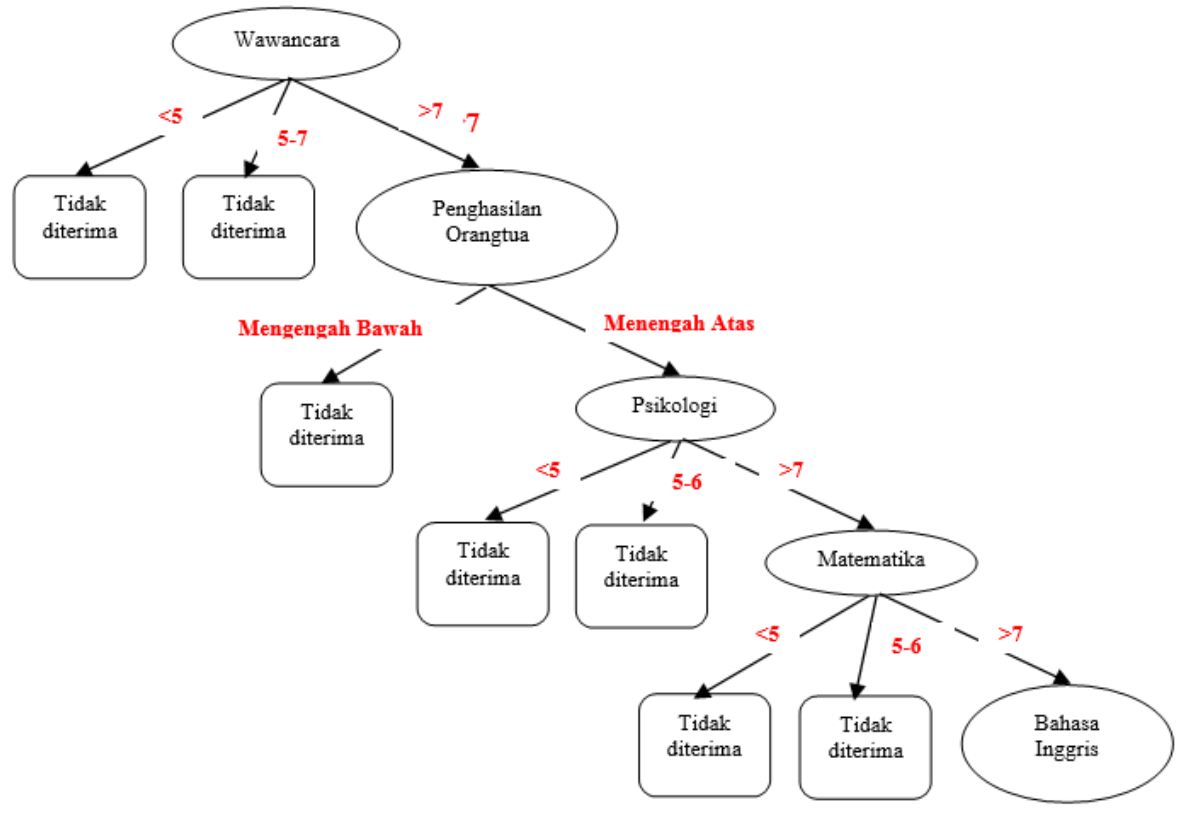

Gambar 4. Pohon Keputusan Menggunakan Algoritma C4.5

\section{SIMPULAN}

Berdasarkan hasil penelitian yang telah dilakukan, dapat disimpulkan beberapa hal sebagai berikut:

a) Model pohon keputusan yang dihasilkan adalah menjadikan Wawancara sebagai akar, Kemudian Penghasilan Orangtua sebagai cabang pada Level 1, Psikologi menjadi cabang pada Level 2, dan Matematika menjadi cabang pada Level 3 dan Bahasa Inggris menjadi cabang pada Level terakhir (Level 4).

b) Proses perhitungan dan penyeleksian seleksi penerimaan calon siwa/i baru menjadi lebih mudah dan cepat dengan menggunakan sistem pendukung keputusan ini. 


\section{DAFTAR PUSTAKA}

[1] Adriyansyah, Dedy. "Faktor-faktor Apa Saja Yang Mempengaruhi Konsumen Listrik Bagi Rumah Tangga Masyarakat Kelurahan Tembung Kecamatan Percut Sei Tuan Kabupaten Deli Serdang." Universitas Sumatera Utara, Medan (2011).

[2] Kusrini, (2009). Algoritma Data Mining, Andi Offcet, Yogyakarta

[3] Arga, Dwi Asih Sapta, Edhy Sutanta, and Uning Lestari. "Implementasi Data Mining Untuk Memprediksi Masa Studi Mahasiswa Menggunakan Algoritme C4. 5 (Studi Kasus: Jurusan Teknik Informatika, Institut Sains \& Teknologi Akprind Yogyakarta)." Jurnal Script 5.1 (2017).

[4] Widayu, Hikma, et al. "Data Mining Untuk Memprediksi Jenis Transaksi Nasabah Pada Koperasi Simpan Pinjam Dengan Algoritma C4. 5." Media Informatika Budidarma 1.2 (2017).

[5] Harahap, Fitriana. "Penerapan data Mining dalam Pemilihan Mobil menggunakan Algoritma C4. 5." Voice Of Informatics 7.1 (2018). 